\title{
Spirituálně laděné intervence v krizové intervenci u sociálních pracovnic křestảanek ${ }^{1}$ Jan Kaňák
}

\begin{abstract}
Abstrakt
Článek pojednává o faktorech, které ovlivňují aplikování spirituálně laděných intervencí v profesionálně pojaté krizové intervenci u sociálních pracovnic, které se účastnily výzkumu o střetávání spirituálního a profesionálního diskursu. V textu je popsáno teoretické ukotvení diskursivního střetávání a v základních obrysech jsou prezentovány potíže s profesionálním diskursem v sociální práci. Následně jsou popsány spirituálně laděné intervence využívané komunikačními partnerkami a faktory, které ovlivňují jejich výběr, stejně jako tři varianty, které jsou výsledkem interakce těchto faktorů.
\end{abstract}

Klíčová slova: spiritualita, spirituálně senzitivní intervence, spirituálně orientovaná intervence, sociální práce, krizová intervence

\section{Úvod}

Článek se zaměřuje na otázku: S ohledem na jaké faktory volí sociální pracovnice křestanky spirituálně laděné intervence $v$ situacích, $k d y$ se střetává profesionální a spirituální diskurs $v$ kontextu krizové intervence? Položená otázka vychází z obecněji pojatého výzkumu, který se zaměřoval na konstrukci dělání sociální práce ${ }^{2} \mathrm{v}$ krizové intervenci v situacích označených jako střetávání profesionálního a spirituálního diskursu. V textu vycházím z uchopení spirituálně senzitivních a spirituálně orientovaných intervencí, které jsou podrobněji popsány jinde 3 . S ohledem na to, že texty, které se spirituálně laděným intervencím věnují, mají převážně deskriptivní charakter (popisují intervenci jako takovou, případně meze využití), ${ }^{4}$ považuji za vhodné doplnit tuto statickou stránku také popisem stránky dynamické. Protože spirituálně laděné intervence souvisí se situací střetávání profesionálního a spirituálního diskursu, budu se věnovat i tomuto konceptu.

1 Vznik tohoto príspěvku byl podpořen grantem Nové výzvy a nová řešení ve veřejné politice a sociální práci (MUNI/A/0784/2017).

2 Dělání sociální práce chápu jako průběžnou re/konstrukci aktivit, jež realizují sociální pracovnice a pracovníci s ohledem na své vlastní pojetí sociální práce (smyslu, cílů, úkolů, definice...), konkrétní klientský systém (klienta a jeho okolí), organizační kontext (hodnoty a pravidla organizace) a (v prrípadě věřících pracovníků a pracovnic) vlastní spiritualitu v situacích konkrétního setkání s klientem.

3 Jan KAŇÁK, Nedefinovaná profesionalita: Vztah diskursů spirituality a profesionality v sociální práci v soudobé odborné literatuře, Sociální práce / Sociálna práca 5/2016, s. 72-92.

4 Srov. Edward R. CANDA - Leola D. FURMAN, Spiritual Diversity in Social Work Practice: The Heart of Helping, Oxford: Oxford University Press, 2010; Ann M. CALLAHAN, Spirituality and Hospice Social Work, New York: Columbia University Press, 2017; David S. DEREZOTES, Spiritually Oriented Social Work Practice, Boston: Allyn and Beacon, 2006 aj. 
Následně v textu popiši metodologický rámec výzkumu a jeho limity. Poslední část článku je věnována odpovědi na výše položenou otázku. Důležitost spirituality v kontextu sociální práce zde budu brát jako předpoklad, o kterém není nutné vést diskuse, byt jsem si vědom, že by jej ne všichni přijali, a to i s ohledem na vývoj vztahu profesionality a spirituality u nás, kdy je charakter vzájemného vztahu stále hledán. ${ }^{5}$

\section{Situace střretávání profesionálního a spirituálního diskursu}

Téma diskursivního střetávání je dle mého soudu v sociální práci aktuální. Jednak se mění charakter profesionálního diskursu (tedy již různá pojetí profesionality a jejich vzájemný kontakt lze považovat za diskursivní střetávání) a zároveň se konkrétní podoba prakticky realizované sociální práce odvijí od výsledku více či méně intenzivního stř̌etávání diskursů různých. ${ }^{6}$ Pro sociální práci je obvyklé, že se v jednotlivých situacích střetává např. právní diskurs s diskursem etiky péče ${ }^{7}$, profesionální diskurs s diskursem manažerským ${ }^{8}$ či profesionální diskurs s diskursem spirituality a náboženství. Sociální pracovnice a pracovníci tak mohou zažívat situace, ve kterých zvažují, zda oznámit již proběhlý trestný čin týrání svěřené osoby, či zda respektovat důvěrnost informací. Situace, $\mathrm{v}$ nichž mohou zvažovat, zda respektovat nařízení vedení organizace o délce kontaktu s klientem, či zda postupovat dle vlastního pojetí sociální práce. Situace, ve kterých mohou zvažovat, zda se s klientem modlit, či nikoliv.

Tyto situace lze označit za diskursivní stř̌etávání, které lze definovat jako situace, ve kterých se setkají dva či více diskursů a tyto diskursy vstoupí do interakce - tedy začnou se vzájemně ovlivňovat. ${ }^{10}$ Toto ovlivňování nemusí být charakteristické jen v komunikaci či interakci, ale také v rámci vnitřního dialogu (např. v situacích, ve kterých pracovník váhá, jak postupovat dál). Nutné je také podotknout, že toto střetávání je situačně ovlivněno, tedy v některých situacích $\mathrm{k}$ němu dochází, $\mathrm{v}$ jiných pracovníci postupují při dělání sociální práce $\mathrm{v}$ souladu s diskursem jedním, byt by se diskurs druhý mohl z vnějšího pohledu zdát podstatný pro další postup. Obecný průběh představuje Baxter ${ }^{11}$ na situaci střetávání dvou diskursů. Autorka formuluje tř̌i možné průběhy střetávání (tabulka č. 1 níže). Bud’ jsou oba dva diskursy akceptovány jako platné pro další situaci konstrukce a navíc vytváŕí nový diskurs, v němž jsou původní jen těžko rozpoznatelné. Tuto variantu označuje autorka jako transformaci. U obou vstupujících diskursů se projevuje centripetální dynamika - tedy posun ke středu další konstrukce a akceptování diskursů.

5 Srov. Jan KAŇÁK, Postavení diskursu spirituality v sociální práci, Sociální práce / Sociálna práca 4/2015, s. 30-46.

6 Srov. Karen HEALY, Social Work Theories in Context, London: Palgrave Macmillan, 2014; Jan KAŇÁK, Diskursivní paleta sociální práce: reflektování diskursů spirituality pomocí prvků diskursivní analýzy, in: Sociální práce v nejisté době, ed. Ondřej ŠTECH - Peter PATYI Zuzana TRUHLÁŘOVÁ, Hradec Králové: Gaudeamus, 2016, s. 23-29; Cathrin MCDONALD, Challenging Social Work: The institutional context of practice, London: Palgrave Macmillan, 2006 aj.

7 Srov. Radka JANEBOVÁ, Dilema mezi právem a etikou aneb právo nezbavuje odpovědnosti, in: Etika sociální práce, ed. Miroslav KAPPL - Martin SMUTEK - Zuzana TRUHLÁŘOVÁ, Hradec Králové: Gaudeamus, 2010, s. 38-54.

8 Srov. MCDONALD, Challenging...

9 Srov. KAŇÁK, Postavení...

10 Srov. Leslie A. BAXTER, Voicing Relationships: A Dialogic Perspective, London: SAGE, 2011.

11 Tamtéž, s. 120-151. 
Tabulka č. 1: Varianty diskursivního střetávání

\begin{tabular}{|l|l|l|l|}
\hline Proces & Dynamika d1 & Dynamika d2 & Výsledek střetávání \\
\hline Transformace & Centripetální & Centripetální & $\begin{array}{l}\text { Vzniká nový diskurs. Průvodní dva } \\
\text { diskursy nejsou v novém rozpozna- } \\
\text { telné. }\end{array}$ \\
\hline $\begin{array}{l}\text { Synchronické } \\
\text { spolu-hraní }\end{array}$ & Centripetální & Centripetální & $\begin{array}{l}\text { Vzniká diskurs, ve kterém jsou ak- } \\
\text { ceptovány oba dva diskursy, jsou ale } \\
\text { rozlišitelné. }\end{array}$ \\
\hline $\begin{array}{l}\text { Diachronická } \\
\text { separace }\end{array}$ & $\begin{array}{l}\text { Centripetální } \\
\text { / centrifugál- } \\
\text { ní }\end{array}$ & $\begin{array}{l}\text { Centripetální / } \\
\text { centrifugální }\end{array}$ & $\begin{array}{l}\text { Vítězí jen jeden diskurs, v souladu } \\
\text { s ním je pak konstruována další } \\
\text { situace. }\end{array}$ \\
\hline
\end{tabular}

V druhé obecnější variantě dochází taktéž k centripetální dynamice u obou vstupujících diskursů. A byt jsou v konstrukci další interakce či situace přítomny oba dva diskursy, je možné při synchronickém spolu-hraní vstupující diskursy v další situaci rozpoznat. Zpravidla pak jeden hraje dominantnější roli, přítomny jsou však oba. Tyto varianty se řídí principem nenulových součtů, tedy oba dva diskursy z ní vycházejí se ziskem. Oproti nim je poslední obecnější varianta dynamiky střetávání charakteristická „logikou nulového součtu“.12 U jednoho diskursu se projeví dynamika centripetální, kdežto u druhého centrifugální a je z další konstrukce situace vyčleněn. Pak se postupuje jen v souladu s diskursem, který při střetnutí zvítězí. Tuto variantu označuje autorka jako diachronickou separaci.

A právě výsledek střetávání mezi profesionálním a spirituálním diskursem ovlivňuje využití spirituálně laděných intervencí. $\mathrm{Na}$ obecné rovině lze, z hlediska střetávání, rozlišovat čistě profesionální sociální práci (která je $\mathrm{v}$ tomto kontextu charakteristická ponecháním spirituality před dveřmi pracovny - tedy pracovník se spiritualitou klienta více nezabývá), čistě spirituální činnost (práce pouze s ohledem na spirituální rovinu klienta) a následně na spirituálně senzitivní a spirituálně orientovanou sociální práci. $\mathrm{V}$ prípadě spirituálně senzitivní sociální práce je se spiritualitou nakládáno jako s jakýmkoliv jiným faktorem sociálního fungování či reflexivního životního zvládání klientů a klientek. Spiritualita je tak spíše verbalizována a, zjednodušeně řečeno, při dělání sociální práce racionalizována. Navíc je předpokládáno, že by součástí dělání sociální práce mělo být také ovlivňování spirituální roviny klienta. $\mathrm{V}$ případě spirituálně orientované sociální práce je pak spirituální rozvoj klienta součástí dělání sociální práce a očekávaných aktivit, pokud se na tom pracovník s klientem shodnou. ${ }^{13}$ Jak bude ukázáno níže, toto členění do jisté míry není zcela vyhovující při popisu dynamiky volby spirituálně laděných intervencí, a proto jej níže rozšíř́m ještě o spirituálně-situačně orientované pojetí.

\section{Potíže s profesionálním diskursem sociální práce}

Definovat diskurs spirituality v sociální práci je sice poněkud složité, protože záleží na tom, do jaké míry je v něm př́tomen rozměr náboženství a s tím související pojetí spirituality, ${ }^{14}$ ale 
v podstatě je s ním relativně méně potíží než s diskursem profesionality. Dříve než se těmto potížím s profesionálním diskursem sociální práce budu věnovat, je nutné ve zkratce říci, že pro tuto práci považuji za diskurs spirituality jeho křestanské pojetí, které by bylo možné charakterizovat jako „zkušenost transformace ve vztahu člověk - Bůh, tak jak to ukázal život Ježišse Krista. Stejně tak je to inspirace Duchem svatým. Křstanská spiritualita je chápána jako životní styl v rámci všech $v z t a h{ }^{\circ}{ }^{15}$. U diskursu profesionality takovouto definici, na které by panovala relativní shoda, nenajdeme.

U různých pojetí diskursu profesionality najdeme na jedné straně spí̌̌e sociologické teze o tom, co je to profese, na straně druhé pak př́stupy, kdy je profesionalita spojována se „zaměřením se na kvalitu praxe " a je zdůrazňována v "rámci odsouhlasených či akceptovaných" intervencí. ${ }^{16}$ Současně je do jisté míry neustále vyjednávána v interakcích sociálních pracovníkủ a pracovnic mezi sebou a s ostatními obory. ${ }^{17}$ To vedlo Payna k pochybnostem o tom, zda „znalostní a hodnotová základna“ sociální práce definuje její profesionalitu, a k nesouhlasu s tím, že by ji odlišovala „od ostatních profesi ${ }^{\text {“ }}{ }^{18}$ Zatímco tedy moderní pojetí diskursu profesionality, které je stále v kontextu sociální práce př́tomno, definuje profesionalitu skrze externí kritéria (možnost sebe-regulace, uvědomění si poslání, autonomie, vlastní vzdělávací instituce aj., př́íp. pro některé také systematická teorie, či etický kodex), ${ }^{19}$ tzv. postmoderní pojetí diskursu profesionality jej zpravidla definují zevnitř, tedy od samotných konkrétních sociálních pracovníků a pracovnic, nebo v případě managerského pojetí profesionality od vedení organizace, či služeb. Objevují se tak pojetí diskursu profesionality jako nestabilního procesu vyjednávání (profesionalita je konstruována $\mathrm{v}$ diskusích mezi sociálními pracovníky uvnitř organizace, či mezi nimi a ostatními profesionály; je otevřena dalším diskursům a pohledům), jako rozvíjejícího se a vynořujícího se procesu učení se praxí, či jako etiky ctností (obsah termínu profesionální je konstruováno podle sociálního pracovníka nebo pracovnice, kteří jsou vnímáni a uznáni jako autority). ${ }^{20}$

To má vliv na způsob, jakým je vhodné téma střetávání diskursu profesionality a spirituality v sociální práci uchopit. Zatímco z moderní perspektivy diskursu profesionality se jedná o dva odlišné diskursy, u některých postmoderních pojetí už to tak jasné není. Například Healy diskurs profesionality vůbec nedefinuje a předpokládá, že na profesionální sociální práci se podílí kombinace různých diskursů. ${ }^{21} \mathrm{Z}$ některých úhlů pohledu lze tedy předpokládat, že spirituálně laděné intervence mohou být chápány jako součást profesionálního diskursu. Pro účely tohoto textu budu ale považovat spirituálně laděné intervence jako aktivity stojící mimo profesionální diskurs (spojený s vědeckým uchopením světa).

15 Donald B. PERRIN, Studying Christian Spirituality, New York: Routledge, 2007, s. 32.

16 Srov. Jon NIXONT et al., Toward a Learning Profession: Changing Codes of Occupational Practice within the New Management Education, British Journal of Sociology of Education 1/1997, s. 6-14.

17 Srov. Andy HARGREAVES, Four Age of Profesionalism and Professional Learning, Teachers and Teaching. History and Practice 2/2000, s. 151-182.

18 Malcolm PAYNE, What is Professional Social Work, Bristol: The Policy Press, 2006, s. 152.

19 Ernest GREENWOOD, Attributes of Profession, Social Work 3/1957, s. 45-55; Robert L. RHODES, Professionalism: A Review of Its Impact on the Health Services, Orthotics and Prosthetics 4/1984, s. 69-74; Harold L. WILENSKY, The Professionalization of Everyone, The American Journal of Sociology 2/ 1964, s. 137-158.

20 Srov. Julia EVETTS, The Concept of Professionalism: Professional Work, Professional Practice and Learning, in: International Handbook of Research in Professional and Practice-based Learning, ed. Stephen BILLET - Christian HARTEIS - Hans GRUBER, New York: Springer, 2014, s. 29-56; Ondřej FISCHER, Potřebuje slušně vychovaný sociální pracovník zákon o sociálních službách?, in: Profesionalita, perspektivy a rozvoj sociální práce, ed. Zuzana TRUHLÁŘOVÁ - Katarina LEVICKÁ, Hradec Králové: Gaudeamus, 2013, s. 115-122; HARGREAVES, Four...; Nigel, M. VERRALL, Social Work Practice and Competing Philosophies, Neo: A Journal of Student Research 1/2010, s. 1-12 aj.

21 Srov. HEALY, Social... 


\section{Spirituálně laděné intervence}

Spirituálně laděné intervence lze vnímat jako specifický projev diskursu spirituality v sociální práci. Míra projevu diskursu následně ovlivňuje to, jestli je primárně oslovována spirituální rovina klienta (spirituálně orientované), či zda se sociální pracovník primárně zaměřuje na reflexivní životní zvládání či sociální fungování (spirituálně senzitivní). V prvním případě je tedy účelem intervencí podpora duchovního růstu (který je v kontextu spirituálně orientované sociální práce chápán jako integrální součást sociální práce), v př́ipadě druhém pak zvládnutí situace, se kterou se klient potýká (přičemž duchovní růst je vnímán jako součást působení jiných profesionálů, at již se jedná o pastorační poradce, kněze, faráře či rabíny aj.). Dříve než v základních rysech představím jednotlivé intervence rozdělené podle toho, zda jsou spirituálně senzitivní, či orientované, budu se v krátkosti zabývat také tím, jakým způsobem mohou sociální pracovníci a pracovnice tyto intervence integrovat do tzv. sady akceptovatelných intervencí. Tu chápu jako celkový rozsah intervencí, technik, aktivit a jednání, které považují sociální pracovníci a pracovnice za přijatelné a vhodné z hlediska dělání sociální práce.

$\mathrm{V}$ podstatě lze očekávat dva obecnější způsoby inkorporace spirituálně laděných intervencí do sady těch akceptovatelných. Prvním z nich je získání vědomostí a dovedností v rámci vzdělávání a výcviků, druhou možností je pak tendence $\mathrm{k}$ „víru integrující profesionalitě. $\mathrm{V}$ tomto procesu dochází $\mathrm{k}$,integraci víry a znalost ${ }^{\varkappa,}, 22$ čímž mají autoři na mysli proces, kdy je do vědomostní báze sociální práce (konstruované na profesionálním diskursu) postupně skrze vlastní zážitky se spiritualitou integrována právě spirituální rovina, resp. $\mathrm{v}$ př́ípadě zde prezentovaného textu $\mathrm{z}$ ní vycházející intervence. Zatímco v prvním případě jsou to autority či druzí lidé, kteří o spirituálně kotvených intervencích referují, stejně jako o možnostech jejich využití pro dělání sociální práce, v př́padě druhém je to integrace vlastních zážitků se spiritualitou a vlastní pojetí spirituality, které se podílí na rozhodnutí, které postupy mohou pracovníci akceptovat pro svoji praxi.

Následující rozdělení spirituálně senzitivních a orientovaných intervencí se opírá o analýzu 74 odborných zdrojů (článků, monografií a konferenčních sborníků), o které je podrobněji referováno $\mathrm{v}$ jiném textu ${ }^{23}$. Mezi spirituálně senzitivní intervence se řadí vytváření prostoru, ve kterém budou klienti zaživat přijetí své spirituality; průběžné kontraktování míry důležitosti spirituality pro klienty a pro zažívanou situaci; domlouvání míry zapojování spirituality do procesu poskytování služeb; zvažování spirituality jako zdroje funkčního i nefunkčního copingu reflexivního životního zvládání či sociálního fungování; případně také doporučování četby duchovních textů; dále duchovní praxe pro podporu v zažívané situaci, nebo podpora v kontaktu s duchovními, pokud se zažívaná situace výrazněji dotýká oblasti spirituálního růstu. Mezi spirituálně orientované intervence jsou pak řazeny, krom spirituálního assessmentu (tedy posouzení důležitosti spirituality pro klienta a zažívanou situaci), také spolupráce s klienty na procesu odpuštění těm, kteř́ jim nějak ublížili; modlení se s a za klienty; podporování klientů ve spirituálním růstu.

\section{Základiní popis metodologického rámce}

Výše položená otázka tohoto textu je formulována v návaznosti na realizovaný kvalitativně zarámovaný výzkum, který se věnoval konstrukci dělání sociální práce při střetávání profesionálního

22 Susan EVANS - Glenda DEVLIN, Client-led Spiritual Interventions: Faith-integrated Professionalism in the Context of Christian Faithbased Organisation, Australian Social Work 3/ 2016, s. 16.

23 Srov. KAÑÁK, Nedefinovaná... 
a spirituálního diskursu v krizové intervenci, a to z pohledu sociálních pracovnic ${ }^{24}$, které samy sebe chápou jako křestanky (a to bez nutnosti aktivní participace v církvi). Pro kriteriální výběr komunikačních partnerek byly stanoveny následující podmínky: a) aktivní výkon profese krizové intervence $\mathrm{v}$ délce nejméně dvou let (alespoň půl roku v organizaci), b) chápání sebe sama jako křestanky a c) pozice sociální pracovnice - jak v rámci sebepojetí, tak v rámci vzdělání. Komunikační partnerky byly oslovovány z těch organizací, které poskytovaly krizovou intervenci ambulantní formou, minimálně 5 dnů $\mathrm{v}$ týdnu a nepracovaly s konkrétněji vymezenou cílovou skupinou (např. obětmi domácího násilí atp.). Souhlas s výzkumem a naplnění těchto podmínek nakonec vedlo $\mathrm{k}$ málo početnému vzorku $(\mathrm{N}=6)$, a tím se nejen tato část výstupu výzkumu řadí k linii kvalitativních výzkumů opírajících se o málo početné vzorky ${ }^{25}$.

Tvorba dat probíhala formou polo-strukturovaných rozhovorů v období 3/2018 až 7/2018. Souběžně s touto fází byla data analyzována (analýza spolu s několika dodatečnými rozhovory pak byla realizována, ještě v období 8/2018 až začátek 9/2018). Zde prezentovaná část výstupů výzkumu je opřena o prvky konstruktivistické varianty zakotvené teorie ${ }^{26}$. Prvotní rozhovory (na které navazovaly dodatečné kratší rozhovory) trvaly v rozmezí 96 až 184 minut. Komunikační partnerky pracují ve třech organizacích, z nichž jedna je zřizována církví (má blíže ke spirituálnímu diskursu). Výzkum byl opřen o techniku kritického incidentu, která spočívá v popisu jednoho konkrétního případu, který se vztahuje ke zkoumanému tématu. Právě málo početný vzorek a využití techniky kritického incidentu jsou výraznějšími limity zde předkládaných výstupů. Oba dva limitující faktory mohly ovlivnit rozsah popisovaných spirituálně laděných intervencí, stejně jako detailnost a různorodost faktorů, které ovlivňují jejich výběr při dělání sociální práce. Tyto limity jsou do jisté míry vyváženy rozdílným spirituálním pozadím komunikačních partnerek (katolické, evangelické, husitské, bez bližší specifikace) a také realizací dodatečných rozhovorů. Data byla zaznamenávána (fixována) na mp3 př̀hrávač s funkcí diktafonu. Následně doslovně transkribována. Po velmi zběžné redukci prvního řádu byly přepisy kopírovány do programu ATLAS.ti verze 7. 5. 18, ve kterém byly kódovány (kódování neprobíhalo striktně podle line-byline coding). Zde prezentovaná zjištění jsou součástí, Interakčního modelu integrace spirituality (IMIS), který vzešel z šíreji zaměřeného výzkumu a u nějž je do budoucna plánováno představení v odborných periodikách a konferencích.

\section{Faktory ovlivňující volbu spirituálně laděných intervencí a varianty volby}

Následující text je rozdělen do tří částí. V první z nich (kapitola 5. 1) bude popsána sada akceptovatelných intervencí, a to s přihlédnutím také k těm, které vycházejí z diskursu profesionality. Větší pozornost bude věnována těm, které jsou spirituálně laděné. V druhé části budou popsány faktory (kapitola 5. 2), které ovlivňují volbu konkrétní spirituálně laděné intervence či spirituálně laděných intervencí. V poslední, třetí části (kapitola 5. 3) jsou stručně popsány výsledné podoby intervencí z hlediska pojmenovaných faktorů. Social Work Practice 1/2014, s. 75-94; George KARPETIS, Advocating the Clinical Social Work Professional Identity, Journal of Social Work Practice 1/2014, s. 23-41 aj. 


\section{1 Sada akceptovatelných intervencí}

O sadě akceptovatelných intervencí (dále také Sada) je potřeba krátce hovořit ze dvou důvodů. Za prvé, právě z této oblasti znalostí a praktických dovedností pracovnice volily intervence. Za druhé se ukazuje, že tato Sada není shodná pro všechny sociální pracovnice. Sada je složená z intervencí, které vycházejí jak z profesionálního, tak spirituálního diskursu. V rámci prvního zmíněného jsou obsahem Sady postupy, které jsou pro krizovou intervenci obvyklé a jsou také získávány na výcvicích krizové intervence. Jde o "takový to řemeslo", kterým je (krom jiného) sada „technik, takový to struktura rozhovoru, aktivní naslouchání a tyhle véci, který patř́ k tomu, jak vést rozhovor" (r2: 016, 018 27). U druhé zmíněné oblasti (vycházející z diskursu spirituality) platí, že intervence pracovnice integrují z vlastního pojetí spirituality, a to proto, že jim na výcvicích nebyl dán prostor. Pokud je téma spirituality do výcviku vneseno, tak „spiš než obecně, tak na ty sekty“ (r3_3: 004 $\left.{ }^{28}\right)$ nebo základní definování „duchovní potřeby při umíráni“ (r5_2: 003) či „něco málo o tý psycho-spirituální krizi ${ }^{29}$ a pak sme si hlavně povídali o tom, jak se mu [lektorovi ${ }^{30}$ ] daří pracovat s lidma, který neberou antipsychotika“ (r1_1: 006). Lze říci, že návody na spirituálně laděné intervence a na to „jak s tím pracovat obecně komunikační partnerky ve výcvicích nedostaly $\mathrm{k}$ dispozici. Zdůrazněno bylo spiše to, „že když hledá [klient] ty otázky víry, tak jít za farářem“ (r3_3: 004). Spirituálně laděné intervence se tedy do Sady dostávají skrze integraci některých aspektů soukromého (nepracovního) života. Z hlediska některých pohledů na dopady diskursu spirituality na aktivity sociálních pracovníků to ale není nic neobvyklého. Pokud je dle některých potřeba „žít hodnotami ve všech rolích a vztazích" ${ }^{\text {31 }}$ a $\mathrm{z}$ nich také čerpat aktivity pro tyto role a vztahy (samozřejmě nikoliv bez ohledu na to, $s$ kým je pracovník zrovna $\mathrm{v}$ kontaktu), lze říci, že diskurs spirituality v kontextu sociální práce s touto prostupností osobního do profesního počítá. Tato zjištění jsou ve shodě s tvrzením Evanse a Devilna, kteří předpokládají, že věřící sociální pracovníci a pracovnice mají tendenci se ve svém profesionálním vývoji přiblížit $\mathrm{k}$ „víru integrující profesionalitě. Předpokládají, že je znalostní báze sociální práce postupně doplňována hodnotami a zkušenostmi ze spirituálního života pracovníku․ ${ }^{32}$ Stejně jako v případě vývoje směrem $\mathrm{k}$ víru integrující profesionalitě i komunikační partnerky doplňují sadu akceptovatelných intervencí, které vycházejí z výcviků, o ty intervence a postupy, které mají zažité ze své vlastní spirituality.

Na tomto místě je důležité zmínit (s ohledem na rozsah textu jen v krátkosti), že se na Sadě podílí také samotné nastavení organizace. Byt počet KP neumožňuje generalizaci, je na vzorku možné popsat rozdíl mezi organizacemi tzv. sekulárními a organizací, která je zřizována církví. V té je totiž, na rozdíl od sekulárních, akceptován projev diskursu spirituality. KP r4 (004 - 010) tak mluví o tom, že v historii organizace měli „takovej modlitební jakože sešit a že se tam napsal klient a za co chce primluvit“ během př́mluv za klienty na poradách týmu. Stejná KP pak popisuje současnou praxi tak, že v rámci porad „máme ztišeniَ. S tím, že „někdo, kdo to má na starosti, tak čte

27 Označení $\mathrm{r} 2$ je využito jako anonymizovaný odkaz k rozhovoru s komunikační partnerkou 2. Č́sla za dvojtečkou v závorce jsou čísla odstavců, které automaticky generoval program ATLAS.ti při kopírování př̌episu rozhovoru.

28 Číslo za podtržítkem označuje pořadí dodatečného rozhovoru s danou komunikační partnerkou. Ostatní viz předchozí poznámka pod čarou.

29 Jedná se o specifický projev krize, která je spojená s duchovními/spirituálními zážitky a na první pohled působí dojmem psychotického onemocnění, kterým ale dle některých není. V Evropě není v MKN-10 k dispozici kód, který by ji označoval, a proto je často ve zdravotnickém kontextu diagnostikována jinak a medikována, což není u tohoto projevu krize zcela vhodné.

30 Takto jsou označena autorem tohoto textu vložená slova, která komunikační partnerky v citované větě nezmínily, ale bez nichž by citace dávala menší smysl.

31 Michael J. SHERIDAN, Spiritual Activism: Grounding Ourselves in the Spirit, Journal of Religion \& Spirituality in Social Work: Social Thought 1-2/2012, s. 204.

32 EVANS - DEVLIN, Client-led..., s. 16. 
něco z Bible, modlíme se, přimlouváme se za klienty“. Církevní zřizovatel tím vytváří prostor pro akceptaci diskursu spirituality jako běžné součásti pracovních činností. Nicméně tento prostor akceptace není vnímán pouze jako bezproblémový. KP pochybuje o tom, že by klienti vnímali toto propojení s církví jako „známku kvality. Pro mnohé klienty to není známka kvality, ale vyvěšená vlajka, a pak si ř́kaj, co mi tam asi budou ř́kat. Nebudou mi tam nutit víru, nebudou mi rozmlouvat rozvod?“. Tyto eventuální obavy, o kterých KP mluví, jsou v souladu s možným rozporuplným vnímáním deklarování vztahu ke konkrétní církvi, na které upozorňují některé současné výzkumy ${ }^{33}$. I tak se ale mezi sebou KP z této organizace liší co do rozsahu spirituálně laděných intervencí v Sadě, a to podle vlastního pojetí spirituality jako takové. ${ }^{34}$ Předběžně tak lze říci, že církevní zřizovatel $\mathrm{v}$ tomto prrípadě vytvárí jakési podhoubí pro využití spirituálně laděných intervencí a jejich konkrétní použití závisí na zhodnocení konkrétní pracovnicí.

Byṫ zaměření výzkumu nekladlo akcent na celospolečenské konsekvence volby intervencí (ty stály $\mathrm{v}$ podstatě mimo výzkumný fokus), je v souladu s tezí o podhoubí a individualizovaných volbách vhodné zmínit také teze o privatizaci náboženství a "moderním náboženském individualismu", $\mathrm{v}$ němž je Bůh vykládán a chápán subjektivně mimo vliv církví. ${ }^{35}$ Fakt, že může být vliv církví na jednotlivce spíše marginální a to i v př́padě vlivu na Sadu a fungování KP zkoumané organizace, naznačuje i KP popisovaný spor o hodnoty poskytování služby, které „voni ${ }^{36}$ vytvářej“ a které jsou vnímány jako „něco diktovanýho". S těmito hodnotami ale v organizaci nepanuje soulad a jsou některými vnímány jako „tak to není, tak to bejt nemůže“ (r6: 060).V českém kontextu pak může určitou roli sehrát i to, že se ke konkrétní církvi nebo náboženské společnosti hlásí (dle SLDB 2011) $14 \%$ obyvatel. ${ }^{37}$ Tento fakt může posílit výše uvedené teze o individualizaci spirituality a „tzv. kompartmentalizaci“" ${ }^{38}$ (tj. odloučení církve od ostatních sfér lidské působnosti i u věřících - tedy i od pracovní). Data výzkumu nicméně neumožňují zodpovědně zvážit, zda jsou volby konkrétních intervencí dány níže popsanými faktory, či zda se jedná o dopad ústupu vlivu církví a jimi definovaných spiritualit na pracovní postupy pracovnic (tedy o součást procesů kompartmentalizace a privatizace náboženství).

V Sadě lze u KP detekovat následující intervence, které jsou pro přehlednost popsány v bodech. Jak bude ukázáno níže, nelze říci, že by všechny komunikační partnerky využívaly všechny spirituálně laděné intervence či je využívaly vždy.

- Zvážení, zda sdělit klientovi, že je pracovník věřící - tedy prezentování vlastního ukotvení ve spiritualitě. Komunikační partnerka - dále také jako KP r4 (012) - mluví o svobodě „mu to říct, nebo neříct. Není to tak, že bych musela, nebo nesměla, ale dycky je to vo logice toho", na co se klient ptá a jak.

- Modlení se za klienty. KP r6 (132) popisuje praxi v organizaci, kdy „tady na poradách máme, že se někdy na začátku modlíme za ty klienty“. Stejně tak KP r5 (086) referuje o tom, že je pro ni „z hlediska tý práce s klientama nesmírně dưležitý, že se za ně můžu modlit“.

- Modlení se s klienty. KP r5 (216) mluví o změně pohledu na modlení se s klienty: „Když se to

33 Kathleen J. MARTIN, Resistance and Change: Visual Culture, Missionazation and Appropriation, In: Indigenous Symbols and Practice in the Cahtolic Church, ed. Kathleen J. MARTIN, Farnham: Asgate Publishing, 2010, s. 9-38.

34 Byt mi rozsah textu neumožní hlubší analýzu, KP r6 (070) považuje spirituálně laděné aktivity v osobním životě za „podporu vztahu $s$ Bohem" a Boha chápe jako toho, kdo dal stvoření svobodu. V její Sadě se neobjevují modlitby za klienty v konkrétních situacích. Oproti tomu KP r5 (058), která je „presvědčená, že působi“ Bůh v lidských životech i v konkrétních situacích, modlení se za konkrétní klienty v konkrétních situacích v Sadě akceptuje.

35 Michaela BARTOŠOVÁ, Mezi Bohem a církví - pluralizace náboženské zkušenosti v římskokatolické církvi, Sociální studia 3-4/2008, s. 90.

36 Rozuměj církevní zřizovatel.

37 Podstatné je také dodat, že $45 \%$ respondentů tohoto cenzu na otázku neodpovědělo.

38 BARTOŠOVÁ, Mezi Bohem..., s. 93. 
stávalo dř́v, tak sem se s těma lidma pomodlila a nějak sem to neřešila. A pak sme si ř́ikali, že bychom to nemèli dělat.“ KP r4 (097) naopak sděluje, že „kdyby klient v tu chvíli řek, jestli se s ním můžu pomodlit, tak řeknu jasně, mủžem a udělám to." Oproti tomu KP r3 (295) nechápe modlitbu s klientem jako soućást práce, a pokud by klient prezentoval potřebu se "pomodlit ve společenství v tom principu, shromáždíli se dva nebo tři v mém jménu, tak je tam Kristus nějak přitomnej." Takovou modlitbu ale nechápe jako součást práce, ale jako jakési vnoření duchovního prostoru (KP je zároveň farářkou) do prostoru krizové intervence a jako vytváření onoho „společenstviّ.

- Ovlivňování spirituální roviny klienta. KP r4 (069) v krátkosti popisuje důvod postupu, ve kterém klientovi rozporovala jeho pojetí přijetí od Boha tím, že „potřebuje vod někoho sly̌set, že nikdy neprestal bejt hoden, že to nestojí na něm ani jeho chování, že spasení není z našich skut$k \mathfrak{k}$, ale z tý druhý strany. "Stejně tak KP r6 $(096,098)$ popisovala ovlivňování klientčina pojetí Boha. Klientka jej vnímala jako toho, kdo způsobuje bolest $\mathrm{v}$ jejím životě. Na to KP reagovala tím, že „sem spiš zdưrazňovala tu Boží lásku, to pozitivní, ten pohled, že to jako nedává smysl to její pojetí Boha.“ Tento pozitivní pohled podporovala argumentem, že pojetí klientky „nedává význam v kontextu dějin spásy, protože to je takovýto středověký pojetí, který bylo hodně mocenský.

- Mapování spirituální dimenze klienta (a to i v případě klientem referované neexistence Boha). KP r3 (123) popisuje kontakt s klientkou, která o sobě ř́kala, že je ateistka tak, že se „ptala, co to znamená bejt ateista a vlastně jako, že ona to popisovala, že kdyby měla říct, v co věř́, tak věři v ten život tady. Takže sme se o tom bavily, ptala sem se, doptávala sem se na to, co pro ní znamená.“ Stejně tak KP r1 (063) popisuje, že když klientka „začala mluvit o Bohu a jaký to pro ni má význam, tak jsem to shrnula, mluvila jsem o tom. "Přičemž toto mluvení o spiritualitě klientky je rámováno jako součást odborného poskytování krizové intervence, „aby to nebylo, že se nějak potkáváme v tý duchovní ćásti jako bratři a sestry v kostele" (r1:057).

- Četba duchovních textů, či veršů z Bible. KP r4 (051) popisuje, v návaznosti na výše zmíněný důvod u Ovlivňování spirituální roviny klienta, jak ,fakt tahám z Bible tydle verše a snažim se mu je dát jako to útěšný, co v tuhle chvíli potřebuje." Stejně tak KP r3 (111) využívá duchovní literaturu, ale jako podklad pro mapování spirituality klienta a vliv na jeho reflexivní životní zvládání: „No, a když už tam něco $z$ tý víry vnesu, tak se o tom bavíme a že tam vnesu nějakou knihu. Třeba Proč se zlé věci stávají dobrým lidem, a furt je to jen o tom, že se bavíme, že ta kniha má zajímavý otázky a zajímavý odpovědi toho pána."

- Zdůraznění Boha jako součásti vztahového pole klientky. KP r1 (117) např. s klientkou kreslila spirituální ecogram tak, že „sem tam nakreslila klientku uprostřed a $k$ tomu jednotlivý postavy, včetně Boha a vztahy, jak jdou před a skrz."

Právě ovlivňování spirituální roviny klienta je oblastí, která mne vedla k potřebě rozlišit spirituálně orientované a spirituálně-situačně orientované intervence. V odborných zdrojích se zpravidla počítá s tím, že je u spirituálně orientovaných intervencí ovlivňována spirituální rovina klienta (jeho pojetí spirituality či vztahu $\mathrm{k}$ Bohu a s Bohem) sama o sobě z důvodu podpory spirituálního růstu. Komunikační partnerky ale popisovaly, že ovlivňování spirituální roviny klienta činí z důvodu podpory stabilizace klienta a zvládnutí krizové situace. Komunikační partnerka r5 (212) zdůvodňuje svůj postup, vedený potřebou zdůraznit, „že Bůh nechce, abychom se báli", tendencí stabilizovat klientku tak, „aby ještě i tohle nebylo to, co je táhne dolư. Intervence, které jsou 
tak řazené pod spirituálně orientovanou sociální práci ${ }^{39}$, zde mají charakter postupů využitých $\mathrm{z}$ důvodů profesionálně (na základě vědecky uchopeného diskursu profesionality) konstruované logiky práce.

\section{2 Faktory ovlivňující volbu konkrétní intervence}

Výběr konkrétních spirituálně laděných intervencí ze sady akceptovatelných intervencí se řídí (v př́padě situací, které KP popisovaly) interakcí faktorů, které ovlivňují, jak moc blízko má v danou chvíli pracovník $\mathrm{k}$ Roli výcvikové profesionality. ${ }^{40} \mathrm{~V}$ krátkosti řečeno, spirituální rovinu považují KP za zásadní pro svůj život a vnímají, „že ta víra není ten kabát, kterej bych mohla odložit,

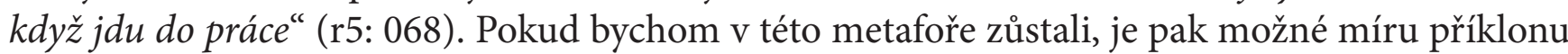
k Roli (se kterou pracovnice vstupují do kontaktu s konkrétním klientem) chápat či vnímat jako konkrétní druh oblečení. Bez ohledu na to, jaký druh oblečení pro ně vykonávání profese je, začínají dělání sociální práce s ohledem na to, že jsou profesně oblečeny. Nicméně tento druh oblečení pak určuje, jaké spirituálně laděné intervence KP využívají. Volbu spirituálně zakotvených intervencí ovlivňuje následujícíit ${ }^{41}$ :

a) obecná míra příklonu k Roli výcvikové profesionality (neboli ono zmíněné oblečení, resp. jeho druh);

b) vnímaná potřeba klienta a možnosti jejího naplnění.

Odborněji by bylo možné označit onu obecnou míru př́klonu k Roli jako reflexivní pracovní plán ${ }^{42}$, který je rozvedením tezí Navrátila o reflexivním životním plánu směrem k uchopení profese sociální práce. ${ }^{43} \mathrm{~V}$ kontextu strukturační teorie je možné nahlížet na obecnou míru př́klonu k Roli jako na prvek „ontologického bezpeč́i “ ${ }^{44}$ Lze ji chápat jako míru blízkosti k vědecky uchopenému diskursu profesionality. Čím blíže má dotyčná KP k takto uchopenému diskursu, tím více využívá jen profesionálně laděných intervencí či těch intervencí, které by bylo možné označit za spirituálně senzitivní. Např́klad modlitbu s klientem tak KP 4 vnímá jako součást profese, kdežto KP 3 nikoliv (viz Modlení se s klienty v předchozí kapitole).

Druhým faktorem, který se podílí na volbě některé ze spirituálně laděných intervencí, je to, jakou potřebu a její možné naplnění u klientů a klientek KP vnímají. Vnímané potřeby je možné rozdělit do dvou obecných oblastí, bud’a) se jedná o potřebu spásy, anebo o b) potřebu zvládnout situaci. Možnost naplnění potřeby je pak vztažena (opět obecně) bud’ směrem k Bohu (a), anebo směrem k interakci KP s klientem (b). Logicky tak vznikají čtyři možné varianty, které jsou popsány v Tabulce č. 2 níže. V tabulce jsou vyjmenovány ty intervence, které zmiňovaly KP, a to bud', že je realizovaly, či že o nich slyšely od kolegů/kolegyň (i z jiných organizací).

39 Srov. DEREZOTES, Spiritually...; KAŇÁK, Postavení...

40 Termín je součástí IMIS. Vyjadřuje to, že KP získaly svůj pohled na profesionalitu v kontextu výcviku v krizové intervenci, v němž byl akcent dán na postupy, které vycházejí z profesionálního diskursu opřeného o vědecky uchopený svět.

41 S ohledem na další plánované články zde považuji za nutné podotknout, že jsou faktory zjednodušeny oproti popisu v rámci IMIS, a to $\mathrm{z}$ důvodu přehlednosti. Myslím si, že logika dynamiky volby tím nebyla změněna.

42 Ten by bylo možné chápat jako představu jednotlivých pracovnic o tom, jak a pomocí jakých intervencí u jakých klientů je možné konstruovat dělání sociální práce.

43 Srov. Pavel NAVRÁTIL, Reflexivní využití teorie v procesu posouzení: Problémy posouzení životní situace v pozdně moderní době Habilitační práce. Brno: FSS MUNI, 2009.

44 Wafa KORT - Jamel E. GHARBI, Structuration theory amid negative and positive criticism, International Journal of Business and Social Research 5/2013, s. 95. 
Tabulka č. 2: vnímaná potřeba u klienti̊ a možnosti jejího naplnění

\begin{tabular}{|l|l|l|}
\hline Potřeba/možnosti naplnění & V interakci Boha & $\begin{array}{l}\text { V interakci lidí (soc. pra- } \\
\text { covník s klientem) }\end{array}$ \\
\hline Potřeba spásy & $\begin{array}{l}\text { V interakcích s klienty se } \\
\text { neprojevuje (z hlediska } \\
\text { rozhovorů s KP) } \\
\text { Předpoklad KP, že budeme } \\
\text { spaseni bez ohledu na naše } \\
\text { jednání na zemi }\end{array}$ & $\begin{array}{l}\text { Tendence změnit spirituální } \\
\text { rovinu klienta, aby odpoví- } \\
\text { dala „podmínkám“ spásy }\end{array}$ \\
\hline Potřeba zvládnout situaci & $\begin{array}{l}\text { Modlení se za klienta } \\
\text { Modlení se s klientem }\end{array}$ & $\begin{array}{l}\text { Změna spirituální roviny } \\
\text { pro zvládnutí situace } \\
\text { Mapování spirituální roviny } \\
\text { pro zvládnutí situace }\end{array}$ \\
\hline
\end{tabular}

Pokud je možnost naplnění vnímána v interakci od Boha směrem ke klientovi, pak je často spojována s omezeným rozsahem zásahu KP směrem ke klientům. KP 5 (096) v tomto kontextu konstatuje, že „sem hodně vnímala tu svoji omezenost, co já můžu nebo nemůžu a tak, že ten Bůh to má nějak pod kontrolou. "V př́padě možnosti naplnění v interakci lidí (KP a klientů) je možnost naplnění potřeby vnímána jako možná i v onom omezeném rozsahu zásahu KP. KP 4 (105) popisuje, jak „tyhle verše já umím a stojím si za nima“. Ve stejné fázi rozhovoru pak sděluje, že „když bude chtít klientka exorcismus, protože si myslí, že v psychoterapii upracovala už dost a tohle sou ty externí, který na ní útočí, tak se jí budu snažit sehnat kontakt. [...] To já taky vím, že to nenížádnej rituál, že tam nelítaj plameny. "Rozdíl mezi těmito dvěma variantami možnosti naplnění je tedy v míře, v jaké KP pro sebe v kontextu potřeby klienta definují situaci jako jimi ovlivnitelnou.

Z hlediska potřeb KP rozlišují potřebu spásy (tedy intervence, které jsou primárně cílené na spásu jako takovou) a potřebu zvládnutí situace. První zmíněná potřeba byla v rozhovorech zastoupena ve formě vzpomínky na kolegyni jedné z KP, pro kterou bylo z pohledu KP v práci s klienty charakteristické „bojovat o Pravdu a hledat univerzální pravdu“. V takovém prrípadě pracovníci následně využívají „ty profesionální prostředky, ale cílem je ta spása“, nebo se s klienty „modlej pro tu spásu“ (r3: 269). V př́padě druhém (tedy potřeby zvládnutí situace) je sice se spiritualitou pracováno (at již je spirituální rovina klienta ovlivňována, či je pouze mapována), ale cílem je „uklidněni“ (r4: 063), či „aby ještě tohle [vlastní spiritualita] nebylo to, co je táhne dolü“ (r5: 212).

\section{3 Od Oslovit Boha ke Zkoumání spirituality}

Sada akceptovatelných intervencí a výše uvedené dva faktory pak ovlivňují to, jak je obecně práce s klienty s využitím spirituálně laděných intervencí strukturována. S ohledem na rozsah textu zde předkládám pouze základní popis jednotlivých variant. V rozhovorech v podstatě zaznívaly především následující tři varianty, které odpovídají vnímané potřebě, aby klient situaci zvládl: ${ }^{45}$

45 Výše popsaná varianta intervencí na spirituální rovině klienta s ohledem na účel spásy klienta zde popsána nebude, a to především proto, že není autentickým postupem práce KP. 
- Modlení se za klienty a s klienty aneb oslovit Boha (spirituálně orientované intervence).

- Změna spirituální roviny klienta pro stabilizaci jeho situace (spirituálně-situačně orientované intervence).

- Zkoumání spirituality pro snadnější orientaci v situaci (spirituálně senzitivní intervence).

$\mathrm{V}$ př́ipadě spirituálně orientovaných intervencí se pro KP zdůrazňuje v modlitbě, že „je tady ještě někdo, komu na klientovi záleží ještě víc než mě. Neznamená to, že by aktivita realizovaná KP s klienty byla jako taková nefunkční, ale „ty mý kompetence končí a ted'už je to na klientovi a na Bohu“ (r4: 006). KP je vnímána „omezenost, co já můžu nebo nemůžu a taky, že ten Bưh to má nějak pod kontrolou“ (r5: 096). Modlitby jsou v tomto smyslu realizovány bud’ jednotlivými pracovníky, nebo (v př́padě, že to umožňuje organizační kultura) také skupinou pracovníků na poradách (jak to popisuje KP r4 - viz výše v kap. 5.1). Zjednodušeně řě̌eno je tímto pro zvládnutí situace oslovován Bůh nikoliv jako výhradní řešitel situace klientů, ale jako Ten, který může mít kontrolu nad situací (viz vyjádření KP r5) a má k dispozici ještě jiné „kompetence“ než pracovník (r4: 006).

$\mathrm{V}$ př́padě spirituálně-situačně orientovaných intervencí je obecným záměrem KP ovlivnit spirituální rovinu klientů, a to pomocí vlastní spirituality. KP r6 (100) popisuje nabízení vlastního pohledu na Boha a na pojetí spásy a Jeho aktivity zde na Zemi, a to s cílem „osvobození $v$ tom, co ona musí, nemusí, aby v tom byla svobodná" v konkrétní situaci krize. KP tak „zdưrazňovala tu Boží lásku, to pozitivní. Ten pohled, že to [pohled klientky] jako nedává smysl to její pojetí Boha“ (r6: 096). Obdobně postupovala KP r4 (051), když „normálně otevřu tu Bibli anebo začnu říkat $z$ hlavy ty verše vo tom, jak fakt jako Bưh je ten, kdo nás utkal v životě naší matky. Jako. Ani výšiny ani hlubiny ani lidská moc nás neodloučí vod lásky Kristovy. "A to v situaci, kdy součástí reakce na krizovou situaci klienta bylo také to, že se necítil hoden Boží lásky. KP pak v tomto př́padě dle vlastních slov ovlivňují skrze vlastní pohled a pojetí Boha či spásy spirituální rovinu klienta nikoliv z důvodu spásy či s cílem dopracovat se s klientem k z něčího pohledu správné víře, ale proto, aby se zmenšil tlak na klienta, a aby spirituální rovina klienta byla pro zvládnutí situace faktorem spíše podpůrným než komplikujícím.

Poslední varianta (spirituálně senzitivní intervence) je, stejně jako předchozí, charakteristická tím, že spiritualita klienta „zapad[á] do kontextu tý [jejich] krize“ (r1: 067). Nicméně spiritualita klientů je v tomto př́padě mapována a zvýrazňována pro klienty v kontextu jejich situací a pro pracovníky s ohledem na potřebu lépe se v situaci krize vyznat (KP r3: 121 mluví o tom, že cítila „velkou potřebu vnitřní si zmapovat, co to znamená“) a jako taková není měněna nebo cíleně ovlivňována. KP r1 (065) mluví o postupu, ve kterém by „nějakým způsobem neovlivňovala [klientku] $v$ tý její víre a zároveň, abych dávala dostatečný prostor pro tu její víru“. V kontextu této teze pak s klientkou vytvářela „obrázek vztahư, v němž zakreslila klientku „uprostřed a $k$ tomu jednotlivý postavy, včetně Boha a vztahy, jak jdou přes a skrz“. Tento postup měl klientce pomoci k „vyznání se ve svý situaci“ (r1: 117).

\section{Závěr}

Předkládaný článek se zaměřuje na otázku: S ohledem na jaké faktory volí sociální pracovnice křestanky spirituálně laděné intervence v situacích, kdy se střetává profesionální a spirituální diskurs $v$ kontextu krizové intervence? Položená otázka, stejně jako její odpověd', vychází z šířeji zaměřeného výzkumu na konstrukci dělání sociální práce v situacích střetávání obou diskursů. Volba 
konkrétní spirituálně laděné intervence je na jedné straně ovlivňována sadou akceptovatelných intervencí (tedy tím, co KP považují pro sebe za intervence, které lze využít v kontextu profesionálně pojaté krizové intervence), na straně druhé pak interakcí dvou faktorů, a to a) mírou příklonu k roli výcvikové profesionality a b) vnímané potřeby klienta a možnosti jejího naplnění. Zjednodušeně řečeno, vyšší př́klon k roli vede u KP k tomu, že volí spíše spirituálně senzitivní intervence než intervence spirituálně orientované. Vnímaná potřeba a možnost jejího naplnění pak ovlivňuje to, zda je intervence vedena s úmyslem mapovat spirituální rovinu (pro snadnější orientaci klienta v situaci), ovlivňovat ji (pro zvládnutí krizového stavu), či oslovit Boha (z důvodů vnímané vlastní omezené kompetence intervenovat do situace klientů).

\section{Kontakt}

Jan Kaňák

HTF UK

Katedra psychosociální věd a etiky

Pacovská 4

14001 PRAHA 4

honza.k@mail.muni.cz 